\title{
Evaluation of All Surgical Margins in Pancreatic Resection Specimens by Proper Grossing Techniques: Surgical Pathology Experience of 285 Cases
}

\author{
Özgür EKINCi iD
}

Department of Medical Pathology, Gazi University Faculty of Medicine, ANKARA, TURKEY

\begin{abstract}
Objective: The aim of this study was to review our series of pancreatic resection specimen handling results and focus on the positivity of the tumor in various retroperitoneal surgical margins.

Material and Method: Our archival cases from 2008 to 2018 were retrospectively examined, especially for the surgical margins. The demographics, tumor locations, and the diagnoses were recorded. The state of all of the retropancreatic surgical margins (anterior, posterior, superior, inferior, superior mesenteric vein and artery) were recorded.
\end{abstract}

Results: There were 285 cases, of which 157 were male and 128 female. The mean and median ages were 63.3 and 64, respectively. Invasive ductal adenocarcinoma was the most common diagnosis [202 cases (70.8\%)]. Positivity was observed in $90(31.5 \%)$ margins. The majority was in the superior mesenteric vein margin [n:24 (8.4\%)]. This was followed by the anterior, resection and SMA margins.

Conclusion: Pancreatic resections should macroscopically be sampled by recommended methods in order to detect positivity in individual margins by proper grossing techniques. When this is applied, the superior mesenteric vein margin is the margin most prone to be positive for the tumor.

Key Words: Pancreatic cancer, Surgical margin, Macroscopy

\section{INTRODUCTION}

Surgical resection is the only curative treatment option for patients with pancreatic adenocarcinoma (1). The handling of the resection specimens in the surgical pathology grossing room should begin with correct anatomical orientation of the sample and recognition of the various retroperitoneal surgical margins. These are anterior, posterior, superior mesenteric vein (SMV), superior mesenteric artery (SMA; also called "uncinate process margin"), superior, inferior and pericholedochal surgical margins. Several grossing methods to evaluate these margins were recommended (26). The common aspect of most of these approaches is to evaluate and report each margin separately.

In this study, a retrospective analysis of the state of the relevant margins of pancreatic surgical specimens was performed with comparison of other similar reports in the literature.

\section{MATERIAL and METHODS}

Pancreatic resection specimens with neoplasms, between 2008 and 2018 were reviewed. All cases with malignant neoplasms and also intraductal papillary neoplasms (IPMN) were included. The gender, ages of the patients at

(Turk Patoloji Derg 2018, 34:242-246)

Received : 23.02.2018 Accepted : 12.03.2018 the time of diagnosis and the location of the tumor in the pancreas were recorded. Tumor locations were grouped as the head, body, tail, ampulla, peri-ampullary, head-bodytail (entire pancreas), intrapancreatic and extrapancreatic choledochal. The hematoxylin\&eosin $(\mathrm{H} \& \mathrm{E})$-stained slides of the surgical margins were re-evaluated and recorded as positive or negative. In addition to the states of the anterior, posterior, SMV, SMA, superior, inferior and pericholedochal surgical margins, bile duct/choledochal surgical margin, the resection margin and state of the serosa of the adjacent duodenum were also recorded. A positive margin was determined to be that in which the tumor touched the inked margin.

\section{RESULTS}

There were 285 cases, of which 157 were male and 128 were female. The male to female ratio was 1.22 . The mean and median ages were 63.3 and 64 years, respectively. The locations of the tumors are shown in Table I. Almost half of the tumors [n:140, (49.1\%)] were located in the head.

The diagnoses and number of the tumors are shown in Table II. The majority were invasive ductal adenocarcinomas, with 202 cases $(70.8 \%)$. Nearly half of these were well-

Correspondence: Özgür EKİNCİ

Department of Medical Pathology, Gazi University Faculty of Medicine, Beşevler 06500, ANKARA, TURKEY

E-mail: ozzyekinci@hotmail.com Phone: +90 3122025488 
Table I: The distribution of the tumor locations.

\begin{tabular}{lc}
\hline Tumor location & Number of patients \\
\hline Head & $140(49.1 \%)$ \\
\hline Body & $13(4.5 \%)$ \\
\hline Tail & $47(16.4 \%)$ \\
\hline Ampulla & $46(16.1 \%)$ \\
\hline Periampullary & $16(5.6 \%)$ \\
\hline Head, body and tail & $3(1.0 \%)$ \\
\hline Intra-pancreatic choledochal & $17(5.9 \%)$ \\
\hline Extra-pancreatic choledochal & $3(1.0 \%)$ \\
\hline Total & $285(100 \%)$ \\
\hline
\end{tabular}

differentiated tumors. This diagnosis was followed by neuroendocrine neoplasms with 31 cases $(10.8 \%)$, of which the overwhelming majority were grade 1 tumors. There were four cases of secondary involvement, three were renal cell carcinomas, and one was gastric signet ring cell carcinoma metastases. One primary diffuse large B cell lymphoma case was present.

Table III shows the number of positive surgical margins crossed against the tumor locations. The tumors located in the pancreatic head had positivity in 67 surgical margins, the most common being the SMV margin [n:23 (16.4\%)]. This was followed by the anterior, resection and SMA margins. The serosa was not involved by tumors located in the head.

Table II: The diagnoses of tumors. Invasive ductal, mucinous adenocarcinomas and neuroendocrine neoplasms are first given in total and the following boxes include the stratification into three grades.

\begin{tabular}{|c|c|}
\hline Diagnosis & Number of patients \\
\hline Invasive Ductal Adenocarcinoma & $202(70.8 \%)$ \\
\hline - Well-differentiated & $104(36.4 \%)$ \\
\hline - Moderately-differentiated & $70(24.5 \%)$ \\
\hline - Poorly-differentiated or signet ring cell carcinoma & $28(9.8 \%)$ \\
\hline Invasive Adenosquamous Carcinoma & $7(2.4 \%)$ \\
\hline Invasive Mucinous Adenocarcinoma & $7(2.4 \%)$ \\
\hline - Well-differentiated & $5(1.7 \%)$ \\
\hline - Moderately-differentiated & $1(0.3 \%)$ \\
\hline - Poorly-differentiated & $1(0.3 \%)$ \\
\hline Neuroendocrine Neoplasm & $31(10.8 \%)$ \\
\hline - Grade 1 & $25(8.7 \%)$ \\
\hline - Grade 2 & $3(1.0 \%)$ \\
\hline - Grade 3 & $3(1.0 \%)$ \\
\hline Mixed Neuroendocrine-Acinar Carcinoma & $1(0.3 \%)$ \\
\hline Mixed Neuroendocrine-Adenocarcinoma & $1(0.3 \%)$ \\
\hline Mixed Neuroendocrine-Serous Neoplasm & $1(0.3 \%)$ \\
\hline Solid Pseudopapillary Tumor & $13(4.5 \%)$ \\
\hline Anaplastic Carcinoma & $2(0.7 \%)$ \\
\hline Undifferentiated Carcinoma - with osteoclast-like cells & $1(0.3 \%)$ \\
\hline Undifferentiated Carcinoma - with rhabdoid component & $1(0.3 \%)$ \\
\hline Intraductal Papillary Mucinous Neoplasm & $10(3.5 \%)$ \\
\hline Acinar Cell Carcinoma & $1(0.3 \%)$ \\
\hline GIST (Gastrointestinal stromal tumor) & $1(0.3 \%)$ \\
\hline Serous Carcinoma & $1(0.3 \%)$ \\
\hline Metastasis & $4(1.4 \%)$ \\
\hline - Renal cell carcinoma & $3(1.0 \%)$ \\
\hline - Gastric signet ring cell carcinoma & $1(0.3 \%)$ \\
\hline Lymphoma (Diffuse large B cell lymphoma) & $1(0.3 \%)$ \\
\hline Total & $285(100 \%)$ \\
\hline
\end{tabular}


This location was followed by the tail, with 8 (17.0\%) foci of positivity in resection, anterior, superior and pericholedochal margins. Serosa involvement was seen in only $3(6.5 \%)$ ampullary tumors and $1(6.2 \%)$ peri-ampullary tumor. The choledochal margin was positive in only 3 cases $(17.6 \%)$ of intrapancreatic choledochal tumors. Three pan-pancreatic (head, body and tail) and 3 extrapancreatic choledochal tumors had no positive margins.
The distribution of the positive margins against the tumor types is presented in Table IV. In 202 invasive ductal adenocarcinomas, 77 (38.1\%) positive margins were present. The most commonly involved margin was SMV with 21 cases (10.3\%). Of the 7 adenosquamous carcinomas, $3(42.8 \%)$ had positive margins.

Table III: The distribution of the positive surgical margins and the serosae based on the tumor locations.

\begin{tabular}{|c|c|c|c|c|c|c|c|c|c|c|c|c|}
\hline & $\begin{array}{c}\text { Number of } \\
\text { patients }\end{array}$ & SMV & SMA & RES & $\mathbf{P}$ & A & $S$ & I & Peri-chol & Chol & Serosa & Total \\
\hline Head & $\begin{array}{c}140 \\
(49.1 \%)\end{array}$ & $\begin{array}{c}23 \\
(16.4 \%)\end{array}$ & $\begin{array}{c}7 \\
(5.0 \%) \\
\end{array}$ & $\begin{array}{c}9 \\
(6.4 \%) \\
\end{array}$ & $\begin{array}{c}5 \\
(3.5 \%) \\
\end{array}$ & $\begin{array}{c}14 \\
(10.0 \%)\end{array}$ & $\begin{array}{c}4 \\
(2.8 \%) \\
\end{array}$ & $\begin{array}{c}1 \\
(0.7 \%)\end{array}$ & $\begin{array}{c}2 \\
(1.4 \%) \\
\end{array}$ & $\begin{array}{c}2 \\
(1.4 \%) \\
\end{array}$ & & $\begin{array}{c}67 \\
(47.8 \%) \\
\end{array}$ \\
\hline Body & $13(4.5 \%)$ & & & $\begin{array}{c}1 \\
(7.6 \%)\end{array}$ & & & $\begin{array}{c}1 \\
(7.6 \%)\end{array}$ & $\begin{array}{c}1 \\
(7.6 \%)\end{array}$ & & & & $\begin{array}{c}3 \\
(23.0 \%)\end{array}$ \\
\hline Tail & $\begin{array}{c}47 \\
(16.4 \%)\end{array}$ & & & $\begin{array}{c}3 \\
(6.3 \%)\end{array}$ & & $\begin{array}{c}2 \\
(4.2 \%)\end{array}$ & $\begin{array}{c}2 \\
(4.2 \%)\end{array}$ & & $\begin{array}{c}1 \\
(2.1 \%)\end{array}$ & & & $\begin{array}{c}8 \\
(17.0 \%)\end{array}$ \\
\hline Ampulla & $\begin{array}{c}46 \\
(16.1 \%) \\
\end{array}$ & $\begin{array}{c}1 \\
(2.1 \%) \\
\end{array}$ & $\begin{array}{c}1 \\
(2.1 \%) \\
\end{array}$ & & & & & & & & $\begin{array}{c}3 \\
(6.5 \%)\end{array}$ & $\begin{array}{c}5 \\
(10.8 \%)\end{array}$ \\
\hline $\mathrm{PA}$ & $\begin{array}{c}16 \\
(5.6 \%)\end{array}$ & & $\begin{array}{c}1 \\
(6.2 \%)\end{array}$ & & & & & & & & $\begin{array}{c}1 \\
(6.2 \%)\end{array}$ & $\begin{array}{c}2 \\
(25.0 \%)\end{array}$ \\
\hline HBT & $\begin{array}{c}3 \\
(1.0 \%)\end{array}$ & & & & & & & & & & & \\
\hline IPCh & $\begin{array}{c}17 \\
(5.9 \%)\end{array}$ & & $\begin{array}{c}1 \\
(5.8 \%)\end{array}$ & & & & & & $\begin{array}{c}1 \\
(5.8 \%) \\
\end{array}$ & $\begin{array}{c}3 \\
(17.6 \%) \\
\end{array}$ & & $\begin{array}{c}5 \\
(29.4 \%) \\
\end{array}$ \\
\hline EPCh & $\begin{array}{c}3 \\
(1.0 \%)\end{array}$ & & & & & & & & & & & \\
\hline Total & $\begin{array}{c}285 \\
(100 \%) \\
\end{array}$ & $\begin{array}{c}24 \\
(8.4 \%) \\
\end{array}$ & $\begin{array}{c}10 \\
(3.5 \%)\end{array}$ & $\begin{array}{c}13 \\
(4.5 \%)\end{array}$ & $\begin{array}{c}5 \\
(1.7 \%)\end{array}$ & $\begin{array}{c}16 \\
(5.6 \%)\end{array}$ & $\begin{array}{c}7 \\
(2.4 \%)\end{array}$ & $\begin{array}{c}2 \\
(0.7 \%)\end{array}$ & $\begin{array}{c}4 \\
(1.4 \%)\end{array}$ & $\begin{array}{c}5 \\
(1.7 \%)\end{array}$ & $\begin{array}{c}4 \\
(1.4 \%)\end{array}$ & $\begin{array}{c}90 \\
(31.5 \%)\end{array}$ \\
\hline
\end{tabular}

SMV: Superior mesenteric vein margin, SMA: Superior mesenteric artery margin, Res: Resection margin, P: Posterior margin, A: Anterior margin, S: Superior margin, I: Inferior margin, Peri-chol: Peri-choledochal margin, Chol: Choledochal margin, PA: Peri-ampullary, HBT: Pancreatic head, body and tail, IPCh: Intrapancreatic choledochal, EPCh: Extrapancreatic choledochal.

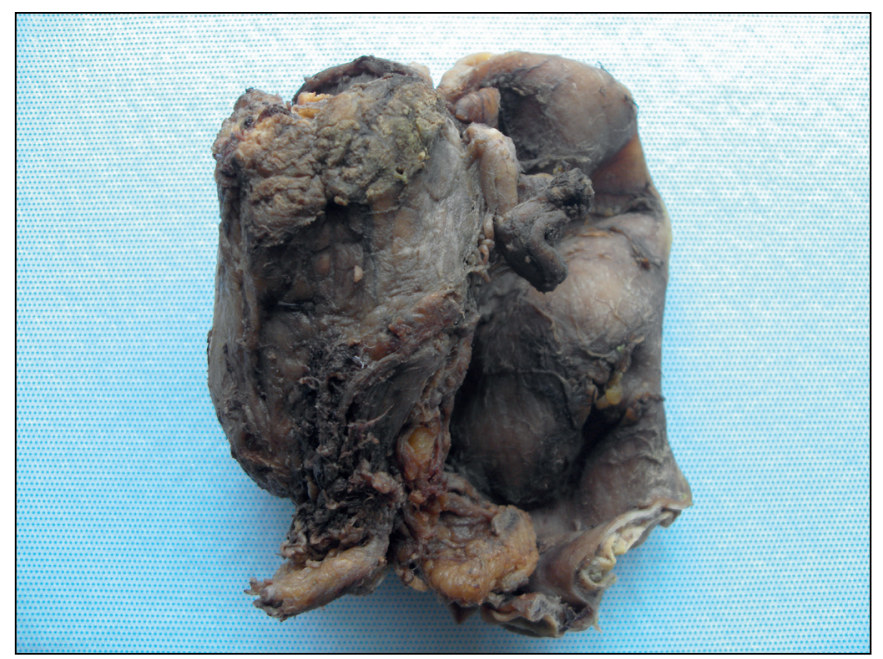

Figure 1: Left lateral macroscopical view of a pancreatic head resection.

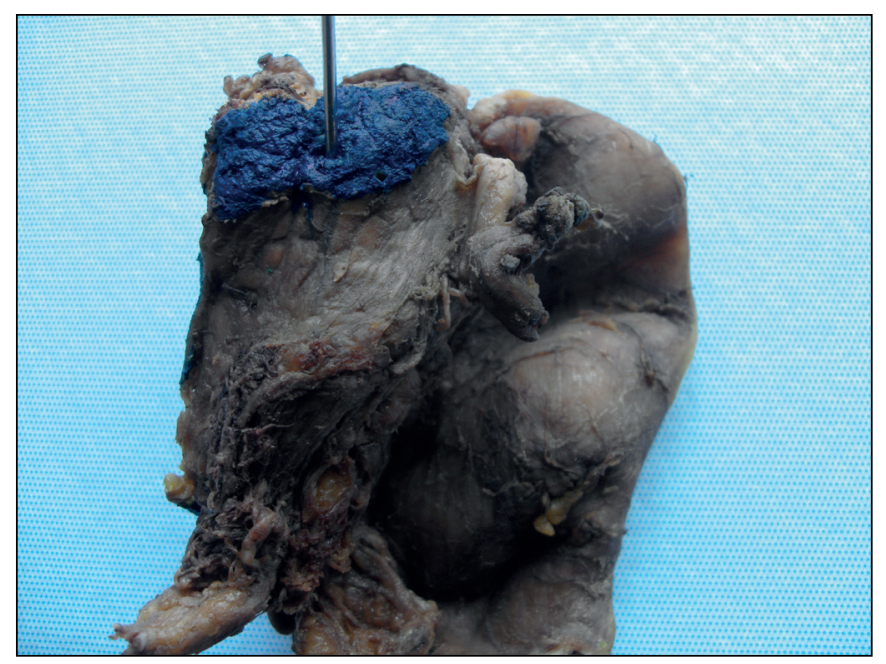

Figure 2: The resection margin is in blue ink. 
Table IV: The distribution of the positive surgical margins and the serosae based on the tumor diagnoses.

\begin{tabular}{|c|c|c|c|c|c|c|c|c|c|c|c|c|}
\hline & $\begin{array}{c}\text { Number of } \\
\text { patients }\end{array}$ & SMV & SMA & Res & $\mathbf{P}$ & A & $S$ & I & Peri-Chol & Chol & Serosa & Total \\
\hline IDA & $\begin{array}{c}202 \\
(70.8 \%)\end{array}$ & $\begin{array}{c}21 \\
(10.3 \%)\end{array}$ & $\begin{array}{c}9 \\
(4.4 \%)\end{array}$ & $\begin{array}{c}11 \\
(5.4 \%)\end{array}$ & $\begin{array}{c}5 \\
(2.4 \%)\end{array}$ & $\begin{array}{c}13 \\
(6.4 \%)\end{array}$ & $\begin{array}{c}5 \\
(2.4 \%)\end{array}$ & $\begin{array}{c}2 \\
(0.9 \%)\end{array}$ & $\begin{array}{c}3 \\
(1.4 \%)\end{array}$ & $\begin{array}{c}4 \\
(1.9 \%)\end{array}$ & $\begin{array}{c}4 \\
(1.9 \%)\end{array}$ & $\begin{array}{c}77 \\
(38.1 \% \\
\end{array}$ \\
\hline IASC & $\begin{array}{c}7 \\
(2.4 \%)\end{array}$ & & & & & $\begin{array}{c}2 \\
(28.5 \%)\end{array}$ & & & $\begin{array}{c}1 \\
(14.2 \%)\end{array}$ & & & $\begin{array}{c}3 \\
(42.8 \%\end{array}$ \\
\hline IMC & $\begin{array}{c}7 \\
(2.4 \%) \\
\end{array}$ & $\begin{array}{c}1 \\
(14.2 \%)\end{array}$ & & & & & $\begin{array}{c}1 \\
(14.2 \%)\end{array}$ & & & & & $\begin{array}{c}2 \\
(28.5 \%)\end{array}$ \\
\hline $\mathrm{N}-1$ & $\begin{array}{c}25 \\
(8.7 \%)\end{array}$ & $\begin{array}{c}1 \\
(4.0 \%)\end{array}$ & & & & & $\begin{array}{c}1 \\
(4.0 \%)\end{array}$ & & & & & $\begin{array}{c}2 \\
(8 \%)\end{array}$ \\
\hline $\mathrm{N}-2,3$ & $\begin{array}{c}6 \\
(2.1 \%)\end{array}$ & & & & & & & & & & & \\
\hline SPT & $\begin{array}{c}13 \\
(4.5 \%)\end{array}$ & $\begin{array}{c}1 \\
(7.6 \%)\end{array}$ & & & & & & & & & & $\begin{array}{c}1 \\
(7 \%)\end{array}$ \\
\hline IPMN & $\begin{array}{c}10 \\
(3.5 \%)\end{array}$ & & & & & & & & & & & \\
\hline Other & $\begin{array}{c}15 \\
(5.2 \%) \\
\end{array}$ & & $\begin{array}{c}1 \\
(6.6 \%) \\
\end{array}$ & $\begin{array}{c}2 \\
(13.3 \%)\end{array}$ & & $\begin{array}{c}1 \\
(6.6 \%) \\
\end{array}$ & & & & $\begin{array}{c}1 \\
(6.6 \%)\end{array}$ & & $\begin{array}{c}5 \\
(33.3 \% \\
\end{array}$ \\
\hline Total & $\begin{array}{c}285 \\
(100 \%) \\
\end{array}$ & $\begin{array}{c}24 \\
(8.4 \%) \\
\end{array}$ & $\begin{array}{c}10 \\
(3.5 \%) \\
\end{array}$ & $\begin{array}{c}13 \\
(4.5 \%) \\
\end{array}$ & $\begin{array}{c}5 \\
(1.7 \%) \\
\end{array}$ & $\begin{array}{c}16 \\
(5.6 \%) \\
\end{array}$ & $\begin{array}{c}7 \\
(2.4 \%) \\
\end{array}$ & $\begin{array}{c}2 \\
(0.7 \%) \\
\end{array}$ & $\begin{array}{c}4 \\
(1.4 \%) \\
\end{array}$ & $\begin{array}{c}5 \\
(1.7 \%) \\
\end{array}$ & $\begin{array}{c}4 \\
(1.4 \%) \\
\end{array}$ & $\begin{array}{c}90 \\
(31.5 \% \\
\end{array}$ \\
\hline
\end{tabular}

SMV: Superior mesenteric vein margin, SMA: Superior mesenteric artery margin, Res: Resection margin, P: Posterior margin, A: Anterior margin, S: Superior margin, I: Inferior margin, Peri-chol: Peri-choledochal margin, Chol: Choledochal margin, IDA: Invasive ductal adenocarcinoma, IASC: invasive adenosquamous carcinoma, IMC: Invasive mucinous adenocarcinoma, N-1: Neuroendocrine neoplasm-grade 1, N-2,3: Neuroendocrine neoplasm, grades-2 and -3 combined, SPT: Solid pseudopapillary tumor, IPMN: Intraductal papillary mucinous neoplasm, the "other" heading includes all of the rest of the tumors.

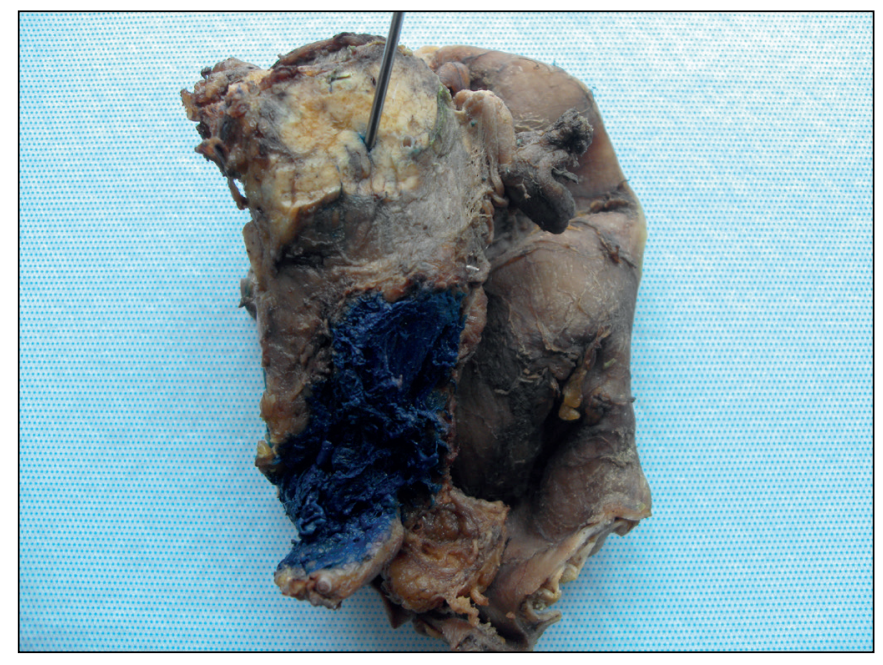

Figure 3: The SMA (superior mesenteric artery) margin is in blue ink.

\section{DISCUSSION}

The majority of the cases included in this study were invasive ductal adenocarcinomas [n:202 (70.8\%)]. The SMV margin was the most commonly involved [n:21 $(10.3 \%)]$. If the tumor was located in the pancreatic head

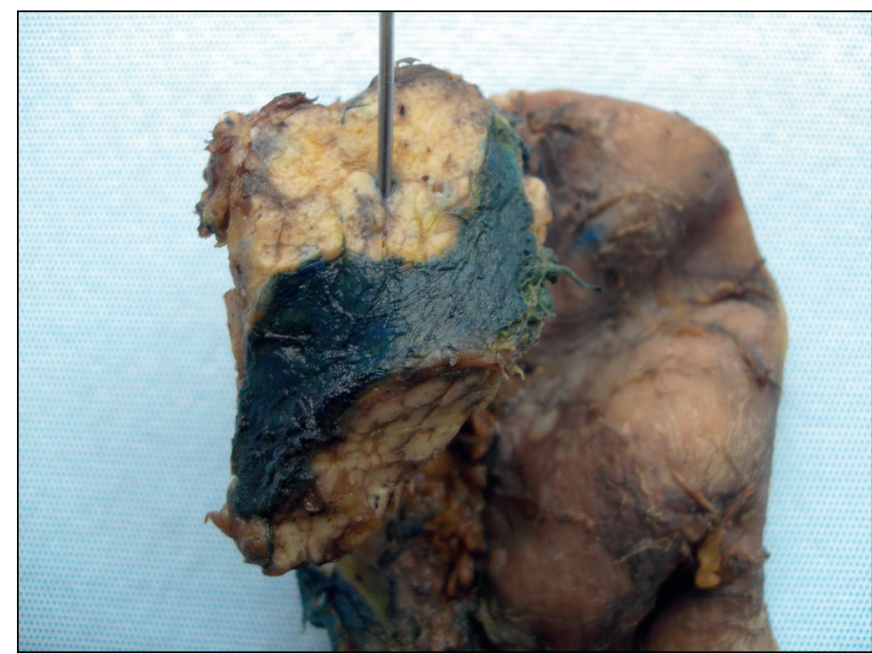

Figure 4: The SMV (superior mesenteric vein) margin is stained with blue ink.

region, there were 67 positive margins (16.4\%). To the best of our knowledge, a detailed documentation of the sites of the positive surgical margins were not presented before. A scrutinized analysis of the patient prognosis is needed, according to the positive margin. 
In view of the personal experiences in our institution throughout the years considering the external consultation cases, it was observed that pancreatic resections appeared to be prone to be handled without special care for the various individual surgical margins and an understanding of the spatial anatomical status of this organ. The pancreas rests in the retroperitoneal space neighboring the superior mesenteric artery and vein adjacent to its uncinate process (Figures 1-4). The smooth groove located supero-medial to the uncinate process is the bed for the superior mesenteric vein, while the irregularly-surfaced area infero-lateral to this spot is the surgical margin for the superior mesenteric artery (2). One report recommended the term "trapezoid" for the threesome adjacency of the resection, SMV and SMA margins (2). Though, we, in routine practice, do not find it clinically helpful to assess the pancreatic duct (Wirsung's) in all cases, this latter report recommends its identification (2). We consider that the whole sampling of the resection margin has more prognostic value than delineating this anatomical structure in pancreatic head resections. On the other hand, in cases of intraductal neoplasms, this procedure may be of benefit in that an intraductal neoplasm may be determined to be located in the pancreatic duct or in one of the branches in this way; that is why we reserve this examination for such cases and do not routinely perform this.

The identification of the choledochal duct (common bile duct) margin is critical in these specimens. Oftentimes, secondary to cautery, usage of staplers or surgical stitches, or the fixation of the specimen in advance, this critical surgical margin might be hard to identify. In our practice, we make use of the anatomic fact that the SMV groove reaches the choledochal stump when this groove is traced supero-posteriorly.

The "R1" status, that is, the presence of a positive margin in the surgical resection specimen, is also under debate and carries prognostic value (7). The ratio of pancreatic resection specimens with positive surgical margins was reported to be $79 \%$ in one study reviewing 167 cases and $80 \%$ in another study with 561 patients $(8,9)$. The latter study found 123 cases with less than $1 \mathrm{~mm}$ to the inked margin and 326 with direct positivity (9). In this recent study, with R0, R1 $(<1 \mathrm{~mm})$, and R1 (direct) status the median survival times and 5-year survival rates were 41.6, 27.5, and 23.4 months; and $37.7 \%, 30.1 \%$, and $20.3 \%$, respectively $(\mathrm{P}<0.0001)(8)$. These researchers claimed that a consensus should urgently be provided to call "what a positive or negative margin is" in pancreatic adenocarcinoma cases (9).

Verbeke et al. have published various articles, recommending an ample and proper gross examination and handling of the pancreatic cancer specimens. In their reports, the dispute over fully-involved margins (R1-direct) and margins clear but within a $1 \mathrm{~mm}$ distance from the tumor (R1-1 mm) was addressed. The vagueness of the decision by the surgical pathologist as to whether the tumor originates from the ampulla, exocrine pancreas or the intrapancreatic bile duct (so called distal bile duct) was also emphasized (3-5).

In conclusion, this study recommends the proper orientation, handling, examination and sampling of pancreas surgical resections. Each of the surgical margins mentioned above should be sampled separately.

\section{CONFLICT of INTEREST}

The author declare no conflict of interest.

\section{REFERENCES}

1. Wagner M, Redaelli C, Lietz M, Seiler CA, Friess H, Büchler MW. Curative resection is the single most important factor determining outcome in patients with pancreatic adenocarcinoma. Br J Surg. 2004;91:586-94.

2. Adsay NV, Basturk O, Saka B, Bagci P, Ozdemir D, Balci S, Sarmiento JM, Kooby DA, Staley C, Maithel SK, Everett R, Cheng JD, Thirabanjasak D, Weaver DW. Whipple made simple for surgical pathologists: orientation, dissection, and sampling of pancreaticoduodenectomy specimens for a more practical and accurate evaluation of pancreatic, distal common bile duct, and ampullary tumors. Am J Surg Pathol. 2014;38:480-93.

3. Verbeke CS, Menon KV. Redefining resection margin status in pancreatic cancer. HPB (Oxford). 2009;11:282-9.

4. Verbeke CS, Leitch D, Menon KV, McMahon MJ, Guillou PJ, Anthoney A. Redefining the R1 resection in pancreatic cancer. $\mathrm{Br}$ J Surg. 2006;93:1232-7.

5. Verbeke CS, Gladhaug IP. Resection margin involvement and tumour origin in pancreatic head cancer. Br J Surg. 2012;99:103649.

6. Westgaard A, Tafjord S, Farstad IN, Cvancarova M, Eide TJ, Mathisen O, Clausen OP, Gladhaug IP. Resectable adenocarcinomas in the pancreatic head: the retroperitoneal resection margin is an independent prognostic factor. BMC Cancer. 2008;8:5.

7. Fatima J, Schnelldorfer T, Barton J, Wood CM, Wiste HJ, Smyrk TC, Zhang L, Sarr MG, Nagorney DM, Farnell MB. Pancreatoduodenectomy for ductal adenocarcinoma: Implications of positive margin on survival. Arch Surg. 2010;145:167-72.

8. Campbell F, Smith RA, Whelan P, Sutton R, Raraty M, Neoptolemos JP, Ghaneh P. Classification of R1 resections for pancreatic cancer: The prognostic relevance of tumour involvement within $1 \mathrm{~mm}$ of a resection margin. Histopathology. 2009;55:277-83

9. Strobel O, Hank T, Hinz U, Bergmann F, Schneider L, Springfeld C, Jäger D, Schirmacher P, Hackert T, Büchler MW. Pancreatic cancer surgery: The new R-status counts. Ann Surg. 2017;265:56573. 